REVISTA CHILENA DE LITERATURA

Abril 2009, Número 74, 251 - 265

\title{
CONQUISTA, RAZA Y RELIGIÓN EN EL EPISODIO DE TEGUALDA: \\ CANTOS XX Y XXI DE LA ARAUCANA
}

\author{
Francisco Ramírez \\ Benemérita Universidad Autónoma de Puebla \\ framirez@post.harvard.edu
}

El encuentro entre el soldado Ercilla y la araucana Tegualda ha sido varias veces objeto de estudio de la crítica ${ }^{1}$. Sin embargo, no se ha agotado aún el aspecto heterodoxo y disidente que subyace a todo el episodio, donde podemos observar cómo el poeta ejerce una crítica radical de diversas cuestiones socio-políticas relacionadas con las minorías conversa y morisca en la España de Felipe II.

Durante una guardia nocturna, Ercilla escucha suspiros, provenientes del campo de batalla donde yacen numerosos araucanos abatidos. En un intento por descubrir su origen, el poeta divisa entre la oscuridad la silueta de una mujer indígena, Tegualda, quien parece estar buscando algo entre los cadáveres. Acto seguido, la araucana, a petición del español, narra los acontecimientos que la orillaron a su aciaga situación y nos enteramos de que la joven busca entre los cadáveres el cuerpo de su esposo, Crepino, para evitar que sea devorado por las fieras salvajes. La tragedia de Tegualda es aún más lamentable debido a que apenas llevaba un mes de casada. Conmovido por el relato de la araucana, Ercilla decide, en vez de tomarla prisionera, prestarle su ayuda. Al siguiente día, en efecto,

1 Lía Schwartz Lerner se acerca al episodio de Tegualda desde el punto de vista de las reminiscencias de los relatos caballerescos (615-625). A su vez, Aura Bocaz parte de los niveles narrativos y analiza la forma en que la inserción de la historia de Tegualda le ayuda al narrador principal a introducir nuevos temas y a crear la impresión de veracidad (7-26). Finalmente, Juan Diego Vila estudia el contrapunto aristótelico de historia y poesía y concluye que "El universo poético de Tegualda permite mostrar lo que debió ser, y, consecuentemente, instalar a la mujer - desde la óptica de la poesía cortesana- en el centro de un orbe, posición en la cual su rol excede el de la preeminencia del hombre, situación ésta históricamente atestiguada" (225). 
Tegualda encuentra a Crepino, abatido por una bala española; el soldado-poeta intenta consolarla, en vano, y, finalmente, le ofrece vía libre para transportar a su esposo a su lugar de origen. La araucana agradece el gesto de buena voluntad y se marcha.

En el relato de Tegualda salen a relucir varios elementos afines al código caballeresco, sobre todo, en el cortejo de Crepino por Tegualda o en la descripción del sitio donde se realizan las fiestas en honor a la araucana (Schwartz Lerner 620-622). Crepino se convierte en un caballero ejemplar, al ponerse al servicio de la dama y ofrecerle sus esfuerzos de acuerdo con las reglas de cortesía establecidas. Asimismo, la lucha de Tegualda entre pasión y recato se inspira en el comportamiento de las damas cortesanas. De manera paralela al contexto caballeresco destaca el tratamiento retórico para la autorrepresentación de la araucana $(\mathrm{xx}, 29-36)^{2}$. En primer lugar, Tegualda, por medio de una técnica de opuestos, se presenta como "viuda, mísera, triste y desdichada" (xx, 29) por quien Ercilla está obligado a mostrar "lástima y piedad" (xx, 29). Más adelante, la araucana le recuerda al combatiente las semejanzas que existen entre ellos y las cuales le permiten a él una mejor comprensión de su situación ("si por ventura / o desventura, como fue la mía, / con amor verdadero y fe pura / amaste tiernamente en algún día" [xx, 30]). Finalmente, Tegualda se sirve de lo que Juan Diego Vila, quien ha estudiado con agudeza el aspecto retórico del discurso de la araucana, define como una técnica moralizante para terminar de involucrar a Ercilla en su destino ("mira que aquel que niega lo que es justo / lo malo aprueba ya y se hace injusto" [xx, 30]).

Sin embargo, más allá de ecos caballerescos o de técnicas retóricas, el episodio encierra una veta política que ha sido hasta ahora solo sugerida por Vila, quien se detiene en la disemia del vocablo querella, utilizado por Ercilla para inducir a la araucana a contar su historia ("donde yo le rogué que su querella / con ánimo seguro y sufrimiento / desde el principio al cabo me contase" [xx, 35]). El investigador acota "que la disemia del término 'querella' no es casual ya que si una primera acepción apunta a la expresión de un dolor físico o sentimiento doloroso, no se debe pasar por alto que también se emplea para designar la acusación ante un juez o tribunal cuyo poder competente en un caso se requiere" (Vila 217). Más adelante, Vila propone una lectura política de los versos que describen el locus amoenus donde se desarrolla la competencia de los pretendientes:

Luego, por orden y artificio estraño, la larga senda y pasos enramaron, pareciéndoles malo el buen camino y que el sol de tocarme no era dino (xx, 41).

Los artificios a los que es sometida la naturaleza subrayan la alta jeraquía de Tegualda, pero dicha preeminencia también puede leerse en términos polémicos, ya que si el espacio del mundo histórico se encuentra sometido a las figuras del imperio y la ley encarnadas

2 Cito a partir de la edición de Marcos A. Morínigo e Isías Lerner (1979); consigno Canto y octava a renglón seguido y entre paréntesis. 
en el monarca español, la figura de Tegualda parece escapar de dicho yugo. Al respecto, Vila apunta que "la alusión a un sol indigno de alcanzarla también puede ser interpretada como una clara referencia al rey de los españoles cuyo imperio, no lo olvidemos, es aquél donde el sol nunca se pone. En el universo poético de Tegualda-parece decirnos Ercilla- las jerarquías son, por cierto, muy otras" (219).

Según se colige, el encuentro de Tegualda con Ercilla es más equívoco de lo que suele asumirse. Se ha argüido, por ejemplo, que el poeta, al presentar a distintas figuras indígenas, como en este caso a Tegualda, bajo una luz positiva, se muestra escéptico de la forma en que se llevó a cabo la conquista de los pueblos americanos por los españoles ${ }^{3}$. Ahora bien, cabe preguntarse si Ercilla nada más está criticando las políticas americanas del imperio o si también está desaprobando alguna situación específica dentro de la misma España. Me inclino a pensar que Ercilla utilizó, al igual que Bartolomé de las Casas -célebre converso, por cierto- la crítica de la conquista de América para evidenciar no solo prácticas represivas y de exterminio de los conquistadores, sino también de la élite gobernante española en la Península ${ }^{4}$. Cuando el poeta describe un encuentro entre un soldado madrileño y una indígena araucana que se resuelve en entendimiento y respeto mutuos dentro de una historia en la que prevalece el genocidio, ¿nada más dirige su mirada hacia América, aunque redacta su obra desde España?

A partir de las precedentes reflexiones se ilustrará cómo el episodio de Tegualda proyecta, a través del drama americano, otro no menos atroz e inhumano: el de los conversos y moriscos españoles. La situación de la araucana, al ser sorprendida por Ercilla sobre el campo de batalla, deviene la del doble cautiverio. El lector del poema, claro está, aún no es consciente de dicha situación, pero a través del relato de la joven se percata de que ella se juzga una cautiva de amor y una cautiva de los españoles. Con sorprendente atención al detalle, Tegualda refiere cómo entregó su libertad a Crepino, a pesar de que ésta era su bien más preciado, lo que la distinguía de las demás y la llenaba de orgullo. Tegualda, incluso, acusa a la fortuna de sentir envidia de ella por la libertad de la que goza ("pero muy presto la fortuna airada / de ver mi libertad y alegre estado" [Xx, 37]). Más adelante, la araucana cuenta cómo despreciaba a sus pretendientes "con franco y libre pensamiento" (xx, 38), sin imaginar que algún día llegararía el fin "desta

3 A favor de esta tesis están, entre otros, William C. Atkinson, C. Pérez Bustamante, José Durand y Juan Diego Vila. En contraste, para Ramón Menéndez Pidal o Isaías Lerner, La Araucana es un poema dedicado a cantar las hazañas españolas en tierras americanas y a ensalzar a Felipe II.

4 Las Casas, a diferencia de Ercilla, vio su causa -la salvación de sus indios- como una visión divina: "Lo que caracteriza eminentemente el papel histórico de Las Casas es su obstinación en procurar, en el mismo centro del poderío español, el total remedio de las Indias, y el haber creído que en este asunto era el enviado de Dios, su portavoz. Como si él respondiera a la llamada de Isaías: 'Clama, ne cesse, quasi tuba exalta vocem', se transforma él mismo en profeta que fustiga a los pecadores y advierte a los reyes" (Bataillon 29). Sobre la impronta del pensamiento lascasiano en Ercilla y otros cronistas de Chile, ver Pérez Bustamante 1952. 
mi libertad y señorío" (xx, 40) y, por eso, vivía "libre a mi parecer y muy segura / de cuidado, de amor y desventura" (xx, 45) ${ }^{5}$. Sin embargo, Tegualda abre finalmente su corazón a un pretendiente-Crepino-a quien, según confiesa a Ercilla, "le di mi libertad y anillo junto" (xx, 66). Crepino, no obstante, es muerto cuando la pareja apenas comenzaba a disfrutar las mieles del amor. A pesar del abatimiento de su marido, en Tegualda aún pervive el amor, por lo que frente a un soldado enemigo su situación vital es la de ser presa de eros y del monarca español.

Poco más de una década antes de que Ercilla diera a la luz pública la Primera Parte de su poema épico, empezó a circular en España El Abencerraje y la hermosa jarifa, una pequeña obra en prosa, que ofrecía entre sus temas centrales el del doble cautiverio ${ }^{6}$. Abindarráez, un moro de la dinastía de los Abencerrajes de Granada y enamorado de Jarifa, es hecho prisionero por el alcalde de Álora, don Rodrigo de Narváez. El moro convence al alcalde de liberarlo para reunirse con Jarifa, bajo la condición de que regrese a entregársele. En brazos de su amada, Abindarráez define su estado: "De suerte, señora que vuestro captivo lo es también del alcalde de Álora" (El Abencerraje 333), corroborando su conciencia del doble cautiverio. Esta circunstancia permite establecer una primera filiación temática entre El Abencerraje y el episodio de Tegualda.

En El Abencerraje descuella, entre otras cosas, que el anónimo autor recurra a una caracterización caballeresca de los moros. Sobre este aspecto, López Estrada registra en su primera edición de la obra: "Los moros de la novela pertenencen a una interpretación poética de una situación histórica, y se les aplicaba la categoría social de la vida caballeresca, y con esto se sobreponían a las particularidades de las 'leyes' consideradas como sistemas de vida cerrados" (284). Esto significa que el autor de El Abencerraje optó por un marco de referencia familiar al público español para dotar de virtudes al otro, es decir, al moro. Probablemente, también Ercilla tenía esta idea en mente al describir positivamente al otro, aunque en su caso se tratase del indígena americano. Al igual que en

5 Ejemplos similares en las octavas 45, 61, 66 y 74 del mismo Canto.

6 Ercilla escribió y publicó su obra entre 1557 y 1589. La primera edición de la Primera Parte data de 1574; es muy probable que la fecha de la primera edición de la Segunda Parte sea 1578; finalmente, la primera edición de la Tercera Parte salió de las prensas en 1589. En su edición de 1957, donde reúne las cuatro versiones que han llegado hasta nosotros de $E l$ Abencerraje, Francisco López Estrada reflexiona sobre la probable cronología: "En 1965 apareció en Medina del Campo un libro misceláneo de Antonio de Villegas intitulado Inventario, entre cuyas páginas se encuentra esta Historia del Abencerraje; en el privilegio se dice que en 1551 el autor ya había solicitado licencia para imprimir la obra. En 1561 el impresor de Valladolid, Francisco Fernández de Córdoba entremetió en el texto de la Diana del poeta Jorge Montemayor un relato con el mismo argumento y con evidentes relaciones con el de Villegas [...]. En fecha que se ignora, y probablemente en Zaragoza, se imprimió otra versión del mismo relato con aspecto de Crónica [...]. Otra versión no tan coincidente con las otras se encuentra en un manuscrito de la Biblioteca Nacional de Madrid" (18-19). 
El Abencerraje en no pocos pasajes del poema épico las actitudes asumidas por diversas figuras araucanas están basadas en códigos caballerescos, según ya se ha advertido ${ }^{7}$.

Por otra parte, la cuestión morisca fue un tema palpitante durante la segunda mitad del siglo XVI hasta la expulsión de los moriscos en 1609. El tema resuena, pienso, en la obra de Ercilla. En varias ocasiones, se establecen analogías o asociaciones entre moriscos y araucanos. Las primeras octavas del Canto xx describen la retirada de Tucapel y sus hombres ante las huestes españolas:

[...] en esto el bando infiel desconfiado, de mucha gente y sangre perdidoso, se retiró siguiendo las banderas que iban marchando ya por las laderas (xx, 14).

Si existía dentro de España un bando infiel a ojos de la mayoría cristiano-vieja, era el de los moriscos, por más que estuvieran bautizados y fueran técnicamente cristianos. Asimismo, en el Canto XVIII, Ercilla "berate[s] the moriscos and the Flemish people as well as the Araucanians, in the 1560s, for denying 'la obediencia al Rey jurada"' (Davies 95).

Por añadidura, las similitudes entre El Abencerraje y el episodio de Tegualda no se agotan con el tema del doble cautiverio, con la representación de moros e indígenas a partir de un código caballeresco común o veladas analogías entre araucanos y moriscos. En ambos textos también prevalece el trato digno hacia los extranjeros: Narváez se muestra muy generoso con Abindarráez y Ercilla hace lo propio con Tegualda. Obsérvese, además, que la joven araucana ya había dado muestras, al aceptar a Crepino como esposo, de confiar en un buen entendimiento e incluso amor entre personas de comunidades distintas. En por lo menos dos ocasiones se reconoce el carácter foráneo de Crepino; una vez cuando está ante Tegualda y le ofrece sus servicios ("que si soy estranjero y no merezco" [xx, 52]) y, otra, cuando la araucana describe la competencia entre Crepino y Mareguano ("pero el mozo estranjero, y corrido / de su poca pujanza y mala maña / alzó de tierra al otro" [xx, 57]).

Otra analogía es que ambos textos se encuentran bajo el signo de la virtud, pues acentúan la dignidad de moros o araucanos, respectivamente. Y, de manera específica, en el episodio de Tegualda asoma la virtud senequista -apuntada por varios críticos en El Abencerraje- que proponía como guía vital repartir beneficios, incluso a los enemigos:

Este término virtud, tan complejo en su significación teórica, se encuentra ilustrado por la práctica de la conducta de los personajes del Abencerraje. La filiación senequista de estas partes de la obra que quedan más cerca de la formulación de los principios expuestos ha sido identificada por los críticos, y así lo demuestro en las notas de esta edición. También J. Gimeno Casalduero ha insistido en este aspecto y lo ha

7 Además del episodio de Tegualda, se puede constatar este tipo de caracterización en el episodio de Lautaro y Guacolda (Canto XIII). 
interpretado como que el autor dirige la obra no ya a un grupo social escogido, sino a todos los españoles que puedan realizar algo análogo en razón de las circunstancias de la política de la nación; por eso escribe el autor del Abencerraje su obra "cuando los ejércitos de España se extienden por el mundo,... el perdonar al vencido y el hacer el bien al necesitado son precisamente la empresa más digna de un capitán español" (López Estrada 1997: 56).

De manera inevitable surge la impresión de que Ercilla, al idear el episodio de Tegualda, hubiese sido afectado por las páginas de El Abencerraje ${ }^{8}$.

Ahora bien, La Araucana sugiere no solo un encuentro entre dos seres que se asisten en la desgracia, sino también una convergencia simbólica de sus personalidades. Al recordar su noche de guardia y justificar su curiosidad por conocer el origen de los suspiros que provienen del campo de batalla, Ercilla utiliza, sin precedente alguno en ese Canto, el pronombre de la primera persona del singular: "Yo de aquella visión mal satisfecho" (xx, 28). Versos más tarde, Tegualda comienza a relatar su historia recurriendo al mismo pronombre, como si quisiera responder a Ercilla y, por extensión, reafirmar su autorrepresentación frente al lector: "Yo soy Tegualda, hija desdichada" (xx, 37); "Yo, que en cosa de aquellas no paraba" (xx, 45); "Yo, que cuando acordé, ya me hallaba / ardiendo" (xx, 61); "Yo, por usar de toda cortesía" (xx, 68) . En el mundo de Ercilla, el sujeto guardaba un mismo valor; en otras palabras: un yo indígena, americano, conquistado y femenino estaba al mismo nivel que un yo español, conquistador y masculino.

Dicha equivalencia se ve consolidada a la luz de sufrimientos amorosos similares. Tegualda, al ver por primera vez a Crepino, siente una gran conmoción:

Yo, que cuando acordé, ya me hallaba

ardiendo en vivo fuego el pecho frío,

alcé los ojos tímidos cebados,

que la vergüenza allí tenía abajados (xx, 61).

Más adelante, Ercilla, extenuado y desesperado, discute, a manera de apóstrofe, con el amor y le solicita una tregua para poder concentrarse en su propósito de relatar hechos bélicos:
¡Ay!, que ya siento en mi cuidoso pecho
labrarme poco a poco un vivo fuego
y desde allí con movimiento blando
ir por venas y huesos penetrando (XXII, 1).

8 Probablemente también hay aquí una influencia decisiva del pensamiento lascasiano: "Según Las Casas, el rasgo más característico de los indios es el parecido que tienen con los cristianos... ¿Qué otra cosa encontramos en su retrato? Los indios están provistos de virtudes cristianas, son obedientes y pacíficos" (Todorov 176).

9 Casi ningún araucano utiliza con mayor frecuencia el pronombre yo como lo hace Tegualda. 
Ambos padecen de forma semejante los embates del amor. Un segundo momento que los "hermana" en el sufrimiento es el dolor que les provoca la memoria. Tegualda le reprocha a su interlocutor su interés por conocer su vida, pues el recuerdo solo ha reabierto las heridas:

Y pues por tu causa la memoria mi llaga ha renovado encrudecida, en recompensa del dolor te pido me dejes enterrar a mi marido $(\mathrm{xx}, 74)$.

Ercilla, escindido entre un sujeto lírico y un proyecto épico, es hostigado por los recuerdos del amor tirano:

¿Tanto, traidor, te va en que yo no siga, el duro estilo del sangriento Marte, que así de tal manera me fatiga tu importuna memoria en cada parte? (XXII, 2).

Ercilla desmonta de esta manera varios argumentos jurídicos de su época, según los cuales la guerra se justifica en caso de superioridad cultural o ley natural. Algunos teólogos y juristas españoles del XVI sostenían que la conquista de América y sus pueblos era justa si ésta tenía como fin la elevación moral del vencido ${ }^{10}$. Sin embargo, Tegualda y su pueblo son portadores de grandes virtudes morales, que incluso, a ojos de Ercilla y sus lectores, son afines a las cristianas.

La Araucana puede leerse como una crítica de la conquista americana por los españoles debido a que ésta, según Ercilla, fue motivada, sobre todo, por razones imperialistas, geopolíticas y económicas resumidas en la palabra codicia ${ }^{11}$. En un controvertible ensayo intitulado “¿Insaciable codicia? ¿Ilustres hazañas?”, Menéndez Pidal arremete contra quienes censuran al imperio español por las atrocidades cometidas durante la conquista de América y asevera que se trata de diatribas provenientes de plumas resentidas como

10 Ver Sepúlveda 1996.

11 Pocas obras cantan con más furia las nefastas consecuencias de la codicia humana: “ $¡ O h$ incurable mal! ¡oh gran fatiga, / con tanta diligencia alimentada! / ¡Vicio común y pegajosa liga, / voluntad sin razón desenfrenada, / del provecho y bien público enemiga, / sedienta bestia, hidrópica, hinchada, / principio y fin de todos nuestros males! / ¡oh insaciable codicia de mortales! // No en el pomposo estado a los señores / contentos en el alto asiento vemos / ni a pobrecillos bajos labradores / libres desta dolencia conocemos / ni el deseo y ambición de ser mayores / que tenga fin y límite sabemos; / el fausto, la riqueza y el estado / hincha pero no harta al más templado. // A Valdivia mirad, de pobre infante / si era poco el estado que tenía, / cincuenta mil vasallos que delante / le ofrecen doce marcos de oro al día; / esto y aun mucho más no era bastante / así el hambre allí lo detenía. / Codicia fue ocasión de tanta guerra / y perdición total de aquesta tierra" (III, 1-3). 
la de fray Bartolomé de las Casas. El célebre filólogo aboga a favor de aquellos historiadores que prestan mayor atención a la voz de los mismos conquistadores en cuyas obras, como en la de Bernal Díaz del Castillo, "al envenenado resentimiento se opone una sencilla y ruda heroicidad llena de interés humano" (citado por Atkinson 31). A guisa de refutación, William C. Atkinson sugiere que hubiera sido aleccionador para el erudito español prestarle mayor atención a La Araucana, donde un conquistador toma la pluma para denunciar los abusos españoles:

“iInsaciable codicia? ¿Ilustres hazañas?” It is a barrier to understanding to formulate these as questions, and a denial of all the evidence to present them as alternatives, either, if conceded, to be taken as excluding the other. Insatiable avarice, deeds illustrious and ignoble, with more of moral ignominy than mere physical valor can atone for: such is the picture of the conquest that emerges consistently from the conquistadores themselves, and that would still be the true picture had there never been a Las Casas (39).

La gran interrogante que aflora a partir del discurso crítico de Ercilla es la de sus motivos. Si bien la hipótesis esbozada por Julio Caro Baroja o Américo Castro ${ }^{12}$ según la cual el poeta tenía orígenes conversos no explica su actitud, sí, por lo menos, permite situarlo dentro de un determinado contexto ${ }^{13}$. Más allá de que dicha ascendencia judía sea confirmada documentalmente fuera de toda duda razonable, el poema brinda ciertos rasgos estilísticos y temáticos, cuyo análisis podría elucidar tan espinosa cuestión. Por ejemplo, Davies rastrea hábitos lingüístico-culturales y muestra que "Ercilla shares the converso's preference for the word ley over religión" (89) y confunde a sus lectores al utilizar la palabra redimir desde una perspectiva cristiana y judía ${ }^{14}$. El investigador

12 Caro Baroja propone una ascendencia judía del lado materno (345-346). Castro es aún más explícito: "En algunas partes, por lo menos en la Rioja, llamaban 'ruanos' a los conversos. Un abuelo de don Alonso de Ercilla, el doctor Alonso Martínez de Nájera, pertenecía, según algunos, 'al estado de los ciudadanos ruanos que llaman conversos"” (La realidad 540).

13 Para Ercilla son también válidos los juicios que el investigador norteamericano Gilman hizo en torno a Rojas o Vives: "Many other examples could be added, and yet, as I said, it would be mistaken to claim that the creation of human and inhuman time by historical times was a converso characteristic. As authors, a Rojas or a Vives or a Fray Luis were not conversos; they were awarenesses subjected to the converso situation" (202).

14 Especifica Davies: "In Catholic Christian teaching [redimir] is associated with both the redemptive act of Christ and a redemption through grace available to the believer by means of the Church and its sacraments, whereas in Judaism it referred to the redemption of the people of Israel” (89-90). Además, el investigador trae a colación varios elementos biógraficos que redondean la tesis conversa: "Attention has hitherto been concentrated on the suspicious genealogical background of the Zúñigas, the poet's family on his mother's side. It may well prove that a different approach will throw into relief a number of equally significant things about the father's side too: his ambiguity of origin, his education and career abroad, 
también estudia la presencia de influencias bíblicas y encuentra que Ercilla equipara la fama de Tegualda con la Judith del Antiguo Testamento (“¡Cuántas y cuántas vemos que han subido / a la difícil cumbre de la fama! / Judic, Camila, la fenisa Dido" [xxI, 3]). Asimismo, Davies acota que "Many of the soldiers, like their leaders, were of converso origin, as their surnames and background suggest" (94). Recordemos que el compañero de Ercilla durante la guardia nocturna se llama Simón Pereira, en cuyo caso el nombre y no el apellido sugieren una filiación conversa. Finalmente, Davies concluye su convincente ensayo con el análisis del problemático tratamiento de los conceptos de clemencia y hermandad.

Más allá de la asociación con la bíblica Judith o del nombre del compañero de Ercilla, el episodio de Tegualda resume una actitud profundamente asociada con la casta conversa: la convicción de que el honor se gana con las propias obras. La sociedad araucana está construida a partir de un planteamiento que favorece los méritos en detrimento del linaje, según explica Ercilla:
Los cargos de la guerra y preeminencia no son por flacos medios proveídos, ni van por calidad, ni por herencia, ni van por hacienda y ser mejor nacidos; mas la virtud del brazo y la excelencia, ésta hace los hombres preferidos, ésta ilustra, habilita, perficiona y quilata el valor de la persona (I, 17).

El poeta no puede menos que mostrar su fascinación por un sistema de gobierno, donde no cuentan la sangre, la herencia o el linaje, sino el esfuerzo propio. Sobre esta inusual organización comenta José Durand: “Lo más insólito de todo, y quizás lo más cautivante entonces, por lo extraño, era que aquellos honrados indios, cuya nobleza aceptaba Ercilla, no tenían la raíz de sus virtudes en el misterioso poder de la sangre heredada, ese poder que universalmente se acepta" (130). El talentoso poeta encontró en suelo sudamericano lo que desde España solo podía ser una utopía. Que Ercilla haya logrado posicionarse bastante bien en la Corte de Felipe II y no haya sido visiblemente discriminado debido a su linaje mancillado, no significa que careciera de una visión crítica respecto a las constantes presiones a las que eran sometidos integrantes de su casta ${ }^{15}$.

the family's connection with sea-borne trade both in Bermeo (Vizcaya) and Seville, the social connections and business contacts of the poet himself and of his wife, their financial activities, and their attempt to obtain the cachet of an unassailable orthodoxy" (86-87). Por otra parte, Medina señala que uno de los padrinos de bautismo de Ercilla fue un tal "Licenciado Monzón", apellido de conversos (284).

15 Sirva de ejemplo lo que fray Luis de León, contemporáneo de Ercilla, escribió por los años en que nuestro poeta redactaba su obra, refiriéndose a la condición de muchos conversos bajo el reinado de Felipe II: "Vasallos viles y afrentados [...], vasallos ruines y viles [...], 
Crepino, el extinto marido de Tegualda, es tal vez el personaje que mejor encarna la idea de que el hombre es hijo de sus obras, pues sus proezas alcanzan los oídos de su futura esposa antes de conocerse. Cuando Tegualda pregunta la razón del alboroto que surge en el lugar de la competencia que se realiza en su honor, un araucano le aclara:

[...] aquel gallardo mozo [Crepino] bien dispuesto

del vestido verde y encarnado,

con gran facilidad le ha en tierra puesto [a Mareguano]

llevándole el honor que había ganado (xx, 48).

Crepino vuelve a vencer a Mareguano en la revancha y, asimismo, sale victorioso de la siguiente prueba. Es de notarse que Crepino, un extranjero, cautiva con su valor y determinación al pueblo de Tegualda y, por extensión, a ella ${ }^{16}$. Y el animoso guerrero americano también impresiona a Ercilla, quien, conmovido por sus hazañas, se ofrece a buscar su cadáver junto a su viuda. A la mañana siguiente encuentran el cuerpo "de una redonda bala atravesado" (XXI, 7), endecasílabo que representa el contrapunto tragicómico a las estrofas 46-66 del canto anterior donde Crepino da la impresión de ser invencible. Si Crepino vencía a sus contrincantes gracias a su velocidad y la fuerza de su brazo, ahora los españoles lo aniquilan recurriendo a una bala traidora que evita el combate cuerpo a cuerpo. El destino del araucano prefigura la queja de don Quijote contra los arcabuces, quien sostenía que dichas armas eran una invención diabólica, pues no respetaban las leyes del honor ${ }^{17}$. En consecuencia, los españoles que lo privaron de su vida carecen de cualquier heroicidad.

Si la hipótesis es correcta de que Ercilla proyecta un conflicto peninsular sobre el episodio de Tegualda, entonces tampoco extraña que nuestro poeta discuta entre sus

generaciones de afrenta que nunca se acaba $[\ldots]$, vasallos apocados y viles $[\ldots]$, un cuerpo social deforme y vil [...], un ganado roñoso [...]" (cit. por Castro, Casticismos 260, n. ${ }^{\circ}$ 9). Castro toma del capítulo "Rey de Dios" del Libro II de De los nombres de Cristo los distintos fragmentos que conforman la cita.

16 Es cierto que en las octavas 70 y 71 del Canto xx se menciona el buen linaje de Crepino, pero esto es solo un elemento más a su favor y no el definitivo como solía suceder en España.

17 Al disertar sobre el valor del soldado en el capítulo 38 de la Primera Parte, don Quijote lanza una invectiva contra el inventor de los arcabuces: "Bien hayan aquellos benditos siglos que carecieron de la espantable furia de aquestos endemoniados instrumentos de la artillería, a cuyo inventor tengo para mí que en el infierno se le está dando el premio de su diabólica invención, con la cual dio causa que un infame y cobarde brazo quite la vida a un valeroso caballero, y que, sin saber cómo o por dónde, en la mitad del coraje y brío que enciende y anima a los valientes pechos, llega una desmandada bala, disparada de quien quizá huyó y se espantó del resplandor que hizo el fuego al disparar de la maldita máquina, y corta y acaba en un instante los pensamientos y vida de quien la merecía gozar luengos siglos" (Cervantes 470-471). 
versos las medidas drásticas que se tomaron hacia los moriscos que se sublevaron contra Felipe II o que haga una analogía entre los "castigos" hechos por las tropas de su rey y las matanzas o persecuciones contra los conversos. En el Canto XVIII se relata la toma de San Quintín por tropas de Felipe II en términos ambiguos, pues si bien se advierte que frente a la heroica defensa de los franceses, los soldados españoles se mostraron impávidos ("mas la gente española, más furiosa, / cuanto topaba más impedimentos, / con temoso coraje y porfiado / rompe lo más difícil y cerrado", [XVIII, 6]), también se detalla cómo dicho valor se metamorfoseó en codicia:
Pero los vencedores, cuando vieron su gran temor y poco impedimento, los brazos altos y armas suspendieron por no manchar de sangre el vencimiento; y sin hacer más golpe arremetieron, vuelto en codicia aquel furor sangriento, al esperado saco de la tierra, premio de la común gente de guerra (XVIII, 17).

Es cierto que muchas veces las tropas invasoras incurrían en el pillaje dentro de las ciudades que ocupaban, pero la semántica del vocablo codicia en este contexto es doblemente equívoca, pues, por un lado, se hace eco de la motivación imperialista que marcó la conquista y, por otro, es asociada al fuego, elemento que no pocos lectores desde España asociaban a la Inquisición:
Como el furioso fuego de repente cuando en un barrio o vecindad se enciende, que con rebato súbito la gente corre con priesa y al remedio atiende [...]
así la fiera gente vitoriosa con prestas manos y con pies ligeros, de la golosa presa codiciosa abre puertas, ventanas $y$ agujeros, sacando diligente y presurosa cofres, tapices, camas y rimeros y lo de más y menos importancia, sin dejar una mínima ganacia (XVIII, 19-20).

De acuerdo con la narración de Ercilla, el siniestro se sale fuera de control y la ciudad se transforma, por unas horas, en un verdadero infierno, donde los franceses terminan muertos en las lanzas de los españoles o calcinados ${ }^{18}$. La equivalencia fuego-codicia

18 "A todas partes gritos lastimosos / en vano por el aire resonaban / y los tristes franceses temerosos / en las contrarias armas se arrojaban, / eligiendo por fuerza vergonzosos / el 
fue común en tiempos de Ercilla donde la Inquisición se distinguió por confiscar el patrimonio de sus convictos. De allí que un converso que escapó milagrosamente de las garras del Santo Oficio prorrumpiera "que el que tenía fazienda feziese cuenta que tenía el fuego consigo" (Baer 473) ${ }^{19}$.

En el mismo Canto XVIII el poeta madrileño aborda la cuestión morisca. De la octava 30 hasta la 65, Ercilla da voz a una visión, en figura de mujer, que vaticina las futuras hazañas de Felipe $\mathrm{II}^{20}$. La profecía se refiere a la guerra entre Francia y España, a la victoria sobre los turcos en Malta en 1565, a los conflictos religiosos en Flandes y, por último, a la revuelta morisca en Granada de los años 1568-1571:

También con pretensión de libertarse,

en el próspero reino de Granada

los moriscos vendrán a levantarse

y a negar la obediencia al Rey jurada [...] (xvIII, 48).

Sin embargo, más adelante se desprende que Ercilla no solo está al tanto de la rebelión de las Alpujarras, sino también de cómo dicho levantamiento fue brutalmente sofocado por don Juan de Austria -a quien, por cierto, está, con gran ironía, dedicado El Abencerraje en la versión de Villegas. Nuestro poeta era consciente de la forma en que España lidiaba con quienes se oponían al proyecto unificador en el terreno político y religioso, pues a la par de las rebeliones moriscas se rememoran las medidas filipinas para evitar la expansión del protestantismo:

[...] mas vuestro Rey, con presta providencia, preveniendo al futuro daño luego, atajará en España esta dolencia con rigor necesario, a puro fuego. Curada la perversa pestilencia, las armas enemigas del sosiego con furia moverá contra el Oriente, enviando al Peñón su armada y gente.

modo de morir que rehusaban / antes que, como flacos, encerrados, / ser en llamas ardientes abrasados" (XVIII, 27).

19 Carlos v instruye a su enviado en Roma en una carta de 1519 que haga todo lo posible por prevenir que Leo x modifique los métodos inquisitoriales españoles, pues esto implicaría dar crédito a las acusaciones que formulaban muchos conversos en el sentido de que la Inquisición actuaba guiada por la codicia: “[...] tal renovación [...] dar[ía] a entender que es verdad lo que falsamente algunos conversos han querido dezir e afirmar que los ynquisidores condemnavan a muchos sin culpa por tomarles sus bienes y haziendas [...]" (Fita 334).

20 La trama de La Araucana está situada en la década de 1550, cuando Ercilla combatió en América, pero la escritura de la Segunda Parte se llevó acabo entre 1570 y 1577 más o menos. 


\begin{abstract}
Aunque no pueda de la vez primera conseguir el efeto deseado volverá la segunda de manera que el áspero Peñon será expugnado y dejando segura la carrera y el morisco contorno amedrentado, por causa de los puertos e invernada retirará la vitoriosa armada (xviii, 35-36).
\end{abstract}

En dos octavas, Ercilla une el destino de religiones distintas al catolicismo, o sea no españolas, a través de un auto de fe, pues A puro fuego se refiere al auto de fe de Valladolid que presenció Felipe II a su vuelta a España en 1559. Se impone pensar que el converso Ercilla, sensible a las imágenes del fuego, encontró similitudes entre el destino de su casta, el de los moriscos y, por extensión, el de los araucanos, estableciendo un vínculo afectivo en el marco de la Conquista, pero más allá de la raza o de la religión, entre él y Tegualda $^{21}$. Ambos están legalmente sometidos a un imperio que no admite la alteridad, que desconoce la tolerancia y donde la cruz es el único símbolo capaz de representar la verdad. Al concluir Tegualda su relato, apunta un sobrecogido Ercilla:
Ya el presuroso cielo volteando en el mar las estrellas trastornaba y el Crucero las horas señalando entre el sur y sudueste declinaba en mitad del silencio y noche, cuando visto cuánto la oferta la obligaba, reprimiendo Tegualda su lamento, la llevamos a nuestro alojamiento $(\mathrm{xx}, 78)$.

El simbolismo es irónico: la narración de Tegualda se desarrolla bajo el Crucero, aquellas "cuatro estrellas notables que hacen entre sí forma de cruz, puestas con mucha igualdad y proporción" (J. de Acosta citado por Lerner en su edición de La Araucana), lo que significa que Ercilla y Tegualda se entienden y ofrecen generosidad mutua más allá de sus distintas religiones bajo la ubicua mirada vigilante del imperio de la cruz.

21 Fray Bartolomé se hizo eco de una idea según la cual los indios eran los descendientes de las tribus perdidas de Israel, lo que posibilitó una identificación entre indios y judíos, pues ambas razas eran sometidas, en opinión del fraile, al exterminio bajo el Imperio español. En la Brevísima, donde proliferan las imágenes del fuego, escribe el dominico: "Hazian unas horas largas [los cristianos] que juntasen [los indios] casi los pies a la tierra: e de treze en treze a honor y reverencia de nuestro redemptor e de los doze apostoles poniendoles leña e fuego los quemavan bivos" (38). Tal parece que a ojos de Las Casas el fuego que calcinaba a conversos víctimas de la Inquisición y a indios americanos era el mismo. 


\section{BIBLIOGRAFÍA}

Atkinson, William C. "Ercilla and the Voice of Conscience". Linguistic and Literary Studies in Honor of Helmut A. Hatzfeld. Ed. Alessandro S. Crisafulli. Washington: Catholic University of America Press, 1964: 31-39.

Baer, Yitzhak. Die Juden im christlichen Spanien. 2 vols. Berlín: Akademie-Verlag, 19291936.

Bataillon, Marcel. Estudios sobre Bartolomé de las Casas. Trad. J. Coderch y J. A. Martínez Schrem. Barcelona: Península, 1976.

Bocaz, Aura. "El personaje Tegualda, uno de los narradores secundarios de La Araucana". Boletín de Filología. 27 (1976): 7-26.

Casas, fray Bartolomé de las. Brevísima relación de la destrucción de las Indias. Prólogo Olga Camps. Barcelona: Fontamara, 1994.

Caro Baroja, Julio. Los judios en la España moderna y contemporánea. Vol. 2. Madrid: Ediciones Arión, 1961.

Castro, Américo. La realidad histórica de España. México: Porrúa, 1954.

Cervantes y los casticismos españoles. Madrid: Alianza, 1974.

Cervantes, Miguel de. El ingenioso hidalgo don Quijote de la Mancha. Ed. Luis Andrés Murillo. 3 vols. Madrid: Castalia, 1978.

Davies, Gareth A. "La Araucana and the Question of Ercilla's Converso Origins". Medieval and Renaissance studies on Spain and Portugal in honour of Peter. E. Russell. Ed. Frederick William Hodcroft et al. Oxford: Society for the Study of Mediaeval Languages and Literature, 1981: 86-108.

Durand, José. “El chapetón Ercilla y la honra araucana”. Filología. 10 (1964): 113-134.

El Abencerraje y la hermosa Jarifa. Ed. Francisco López Estrada. Madrid: Publicaciones la Revista de Archivos, Bibliotecas y Museos, 1957.

Ed. Francisco López Estrada, Madrid: Cátedra, Madrid, 1997.

Ercilla, Alonso de. La Araucana. Ed. Marcos A. Morínigo e Isaías Lerner. Madrid: Castalia, 1979.

La Araucana, Ed. Isaías Lerner, Cátedra, Madrid, 1998.

Fita, Fidel. "Los judaizantes en los cinco primeros años (1516-1520) del reinado de Carlos I. Una investigación histórica”. Boletín de la Real Academia de Historia. 33 (1898): 307-348.

Gilman, Stephen. The Spain of Fernando de Rojas. The Intellectual and Social Landscape of "La Celestina". Princeton: Princeton University Press, 1972.

Medina, José Toribio. Vida de Ercilla. México: Fondo de Cultura Económica, 1948.

Pérez Bustamente, Ciriaco. "El lascasismo en La Araucana". Revista de estudios políticos. 64 (1952): 157-168.

Schwartz Lerner, Lía. "Tradición literaria y heroínas indias en La Araucana”. Revista Iberoamericana. 38 (1972): 615-625. 
Sepúlveda, Juan Ginés. Tratado sobre las justas causas de la guerra contra los indios. México: Fondo de Cultura Económica, 1996.

Todorov, Tzvetav. La Conquista de América. El problema del otro. Trad. Flora Botton Burlá. México: Siglo XXI Editores, 1987.

Vila, Juan Diego. "El personaje de Tegualda y su doble iniciación (histórica y poética) en $L a$ Araucana de Ercilla". Signos. 25 (1992): 213-225.

Palabras clave: La Araucana, Alonso de Ercilla, Tegualda, conversos, moriscos.

KEY WORDS: La Araucana, Alonso de Ercilla, Tegualda, conversos, moriscos. 